\title{
ANALISIS DISIPLIN KERJA PADA SALES PROMOTION GIRL (SPG) \\ DAN SALES PROMOTION BOY (SPB) (Studi kasus pada MDS Paragon Semarang)
}

\author{
Mauliya Siti Aisyah \\ Teguh Ariefiantoro
}

Fakultas Ekonomi Universitas Semarang

Diterima: Mei 2019, Disetujui: Juni 2019, Dipublikasikan: Juli 2019

\begin{abstract}
The study was conducted in MDS Paragon Semarang City. The purpose of this study was to analyze what factors are the causes less optimal of employees' of work discipline.

The study used a qualitative method, by using data source triangulation namely observation, interviews, and documentation. The study based on the principle of suitability informants appropriateness and adequancy. Based on the principle that on informant in a study of 3 people.

From the results of this study indicate what factors are the causes of less of optimal discipline, namely discipline, leadership, motivation, work environment, job satisfaction and work culture.
\end{abstract}

Keywords: discipline, leadership, motivation, work environment, job satisfaction, and work culture.

\begin{abstract}
ABSTRAK
Penelitian ini bertujuan untuk mengetahui perbedaan keputusan pembelian, motivasi dan persepsi produk batik antara konsumen pria dan wanita di Surakarta.

Jenis penelitian ini menggunakan metode deskriptif komparatif. Populasi penelitian ini adalah jumlah total konsumen pria dan wanita di PGS dan Pasar Klewer yang jumlahnya tidak terbatas. Sampel dalam penelitian ini berjumlah 100 responden (50 responden PGS dan 50 responden Pasar Klewer) menggunakan teknik non-probability sampling, yaitu metode purposive sampling dan convenience sampling. Teknik analisis data dalam penelitian ini menggunakan uji t sampel independen.

Analisis menunjukkan bahwa ada perbedaan yang signifikan dalam keputusan pembelian dan motivasi konsumen antara konsumen pria dan wanita, tetapi tidak ada perbedaan dalam persepsi konsumen antara konsumen pria dan wanita.
\end{abstract}


Kata kunci: Keputusan Pembelian, Motivasi Konsumen, Persepsi Konsumen, Gender

\section{PENDAHULUAN}

Sehubungan dengan itu pengelolaan sumber daya manusia merupakan hal yang sangat penting mendapat perhatian, karena untuk mencapai tujuan pembangunan nasional dan perlu memobilisir segala sumber - sumber data yang ada termasuk sumber daya manusia. Gerry Dessler (2011) berpendapat bahwa : “ Human resource management is the process acquiring, training, appraising, and compensating employees, and attending to their labor relations, health and safety and fairness concerns." Manajemen sumber daya manusia adalah proses memperoleh, melatih, menilai, dan memberikan kompensasi kepada karyawan, memperhatikan hubungan kerja mereka, kesehatan, keamanan, dan masalah keadilan. Masalah sumber daya manusia merupakan salah satu permasalahan pokok yang dihadapi negara - negara berkembang seperti Indonesia dalam rangka pembangunan bangsa dan negaranya. Sumber daya manusia (karyawan) menjadi sorotan maupun tumpuan bagi perusahaan untuk tetap dapat bertahan. Walaupun banyaknya sarana dan prasarana serta sumber daya, tanpa dukungan sumber daya manusia kegiatan perusahaan tidak akan berjalan dengan baik. dengan demikian sumber daya manusia merupakan kunci pokok yang harus diperhatikan dalam segala kebutuhan. Sumber daya manusia akan menentukan keberhasilan pelaksanaan kegiatan perusahaan. Untuk itu, dalam mencapai tujuan organisasi dibutuhkan kompetensi sumber daya manusia yang memadai dalam mendorong kinerja karyawan.

Perusahaan akan berkembang dan mampu bertahan dalam lingkungan persaingan yang kompetitif apabila didukung oleh karyawan-karyawan yang kompeten dibidangnya. Seperti yang diungkapkan oleh Spencer (Moeheriono, 2014) bahwa kompetensi karyawan terdiri dari Knowledge (Pengetahuan), Skills (Keterampilan), SelfConcept (Konsep Diri), Traits (Watak/Karakteristik Pribadi), dan Motives (Motif).Semakin banyak kompetensi yang dimiliki seorang karyawan maka semakin meningkat pula kinerjanya.Meningkatkan kinerja karyawan secara efektif pada suatu perusahaan mutlak diperlukan karena merupakan tingkat 
pencapaian hasil atau pelaksanaan tugas tertentu dalam rangka mewujudkan sasaran dan tujuan lembaga atau perusahaan. Dengan demikian kinerja karyawan berhubungan erat dengan produktivitas seseorang dalam melaksanakan tugas dan tanggung jawabnya di perusahaan. Kinerja karyawan salah satunya dipengaruhi oleh disiplin kerja yang baik.

Semakin banyak pegawai yang memiliki kinerja maksimal maka produktivitas organisasi secara keseluruhan akan meningkat sehingga visi dari organisasi bisa terwujud. Pada hakikatnya kinerja pegawai merupakan prestasi yang dicapai oleh seseorang dalam melaksanakan tugasnya atau pekerjaannya sesuai dengan standar dan kriteria yang ditetapkan untuk pekerjaan itu. Menurut Rivai \& Sagala (2013) disiplin kerja adalah suatu alat yang digunakan para manajer untuk berkomunikasi dengan karyawan agar mereka bersedia untuk mengubah suatu perilaku dan untuk meningkatkan kesadaran juga kesediaan seseorang agar menaati semua peraturan dan norma sosial yang berlaku di suatu perusahaan. Sejalan dengan Rivai \& Sagala, bagi Sintaasih \& Wiratama (2013), disiplin kerja adalah merupakan tindakan manajemen untuk mendorong kesadaran dan kesediaan para anggotanya untuk mentaati semua peraturan yang telah ditentukan oleh organisasi atau perusahaan dan norma-norma sosial yang berlaku secara sukarela.

Kedisiplinan bukan berarti ketepatan waktu saat datang dan pulang, melainkan juga kedisiplinan dalam melaksanakan tugas dan fungsi yang seimbang sebagaimana telah diuraikan dalam uraian jabatan. Ketika pegawai mampu melaksanakan seluruh tugas dan fungsi yang melekat pada dirinya, maka pegawai tersebut dapat dikatakan berdisiplinan dan berdedikasi yang tinggi.

Disiplin yang baik mencerminkan besarnya rasa tanggungjawab seseorang terhadap tugas - tugas yang diberikan kepadanya. Hal ini mendorong gairh kerja, semangat kerja, dan terwujudnya tujuan perushaan. Semakin baik disiplin karyawan, semakin tinggi prestasi kerja yang dapat dicapai dengan optimal. Seperti halnya kedisiplinan karyawan di Matahari Department Store (MDS) Paragon Semarang, disiplin karyawan dalam perusahaan menjadi penentu keberhasilan perusahaan. Disiplin karyawan yang baik akan mempercepat 
pencapaian tujuan organisasi, sedangkan disiplin yang merosot akan menjadi penghalang dan memperlambat pencapaian ujuan organisasi.

MDS Paragon Semarang merupakan perusahaan yag bergerak di bidang fashion dan kebutuhan rumah tangga. Seiring perkembangan dan pertumbuhan ekonomi yang berdampak kepada perubahan gaya hidup dan kebutuhan masyarakat, menjadikan MDS Paragon Semarang sebagai peritel pilihan utama konsumen dalam berbelanja. MDS Paragon Semarang adalah usaha di bidang fashion dan konsisten menawarkan produk bernilai dan tepat guna dengan pelayanan terbaik guna peningkatan kualitas dan gaya hidup konsumen. Oleh karena itu, disiplin kerja karyawan sangat penting di MDS Paragon Semarang.

Disiplin kerja MDS Paragon Semarang didasarkan pada pelaksanaan SOP peraturan perusahaan PT. Matahari Deprtement Store Tbk periode 2018 - 2020 Pasal 41 tentang Tata Tertib Kerja Sales Promotion Girl (SPG) Dan Sales Promotion Boy (SPB). Yang peraturannya antara lain berisi bahwa setiap karyawan tidak diijinkan :

1. Melakukan kegiatan - kegiatan yang bertentangan dengan kepentingan perusahaan dan/atau hak asasi mausia di lingkungan kerja.

2. Duduk - duduk, bersenda gurau,, mengobrol, makan - minum, dan/atau mengunyah permen selama menjalankan tugas di area penjualan.

Dari peraturan SOP perusahaan PT. Matahari Department Store Tbk, terjadi ketidaksesuaian antara SOP dan fakta yang terjadi di lapangan. Berikut adalah fakta - fakta yang terjadi dan dilakukan oleh karyawan MDS Paragon Semarang yaitu :

TABEL 1.1

Fakta yang terjadi di Lapangan terkait dengan Disiplin Kerja Karyawan

\begin{tabular}{|l|l|}
\hline NO & Fakta Masalah - Masalah Kurang Optimalnya Disiplin Kerja Karyawan \\
\hline 1 & Karyawan duduk - duduk di jam kerja \\
\hline 2 & Beberapa karyawan terlihat megobrol di area penjualan \\
\hline 3 & $\begin{array}{l}\text { Adanya kesalahpahaman yang menyebabkan cek cok antara karyawan yang } \\
\text { satu dengan yang lain, bahkan saling mendiamkan sehingga kondisi bekerja } \\
\text { terasa kurang nyaman }\end{array}$ \\
\hline 4 & Mengunyah permen di saat menjalankan tugas di area penjualan \\
\hline 5 & Menyimpan barang di gudang dan wagon (rak) untuk kepentingan pribadi \\
\hline
\end{tabular}

Sumber : Data primer yang di olah, 2019 
Dari permasalahan dalam tabel 1.1 diatas menunjukkan garis besar masalah masalah kurang optimalnya disiplin kerja karyawan MDS Paragon Semarang.

\section{LANDASAN TEORI}

\section{Manajemen}

Manajemen merupakan suatu ilmu dan seni untuk menerapkan fungsifungsi perencanaan, pengorganisasian, pengarahan, dan pengendalian pada kegiatan-kegiatan sekelompok manusia yang dilengkapi dengan sumber ekonomi (faktor produksi) untuk mencapai tujuan yang telah ditetapkan dan ditentukan oleh perusahaan sebelumnya. James A.F. Stoner yang diterjemahkan oleh Alexander Sindoro (2010) mengemukakan bahwa manajemen adalah suatu proses perencanaan, pengorganisasian, kepemimpinan, dan pengendalian upaya anggota organisasi serta penggunaan semua sumber daya yang ada pada organisasi untuk mencapai tujuan organisasi yang telah ditetapkan sebelumnya.

\section{Manajemen Sumber Daya Manusia}

Manajemen Sumber Daya Manusia atau yang disingkat sebagai manajemen SDM adalah sebuah rangkaian proses untuk dapat menangani permasalahan-permasalahan yang terjadi dalam lingkup karyawan, buruh, manajer, dan tenaga kerja yang lainnya supaya mampu menunjang kegiatan perusahaan untuk dapat mencapai tujuan perusahaan yang telah ditentukan. Umumnya, bagian atau unit yang menangani sumber daya manusia yaitu departemen sumber daya manusia yang biasa disingkat HRD (Human Resource Departement). Veithzal Rivai (2014) mengemukakan bahwa manajemen sumber daya manusia adalah salah satu bidang dari manajemen umum yang meliputi segisegi perencanaan, pengorganisasian, pelaksanaan dan pengendalian.

\section{Kedisplinan}

Kata disiplin itu sendiri berasal dari Bahasa Latin "discipline" yang berarti "latihan atau pendidikan kesopanan dan kerokhanian serta pengembangan tabiat". Disiplin muncul sebagai usaha untuk memperbaiki perilaku individu sehingga taat azas dan selalu patuh pada aturan atau norma yang berlaku. Menurut Hasibuan 
(2016) menyatakan bahwa kedisiplinan adalah kesadaran dan kesediaan seseorang menaati semua peraturan perusahaan dan norma - norma sosial yang berlaku.

\section{Kepemimpinan}

Kepemimpinan merupakan faktor yang menentukan dalam suatu perusahaan. Berhasil atau gagalnya perusahaan dalam mencapai suatu tujuan dipengaruhi oleh cara seorang pemimpin. Sosok pemimpin dalam perusahaan dapat menjadi efektif apabila pemimpin tersebut mampu mengelola perusahaannya dan mempengaruhi perilaku bawahan agar mau bekerja sama dalam mencapai tujuan perusahaan. Menurut Robbiins (2016) kepemimpinan adalah kemampuan untuk mempengaruhi suatu kelompok menuju pencapain sebuah visi atau tujuan yang di tetapkan. Dari pengertian tersebut dapat disimpulkan bahwa pengertian dari kepemimpinan adalah seseorang yang memiliki wewenang untuk melakukan pengorganisasian terhadap pegawai atau bawahannya untuk bersedia dengan senang hati mengikui kehendak pemimpin.

\section{Motivasi}

Menurut Robbins (2016) motivasi adalah proses yang berperan pada intensitas, arah dan lamanya berlangsung upaya individu ke arah pencapaian sasaran. Menurut Danim (2012) Motivasi (motivation) diartikan sebagai kekuatan, dorongan, kebutuhan, semangat, tekanan, atau mekanisme psikologi yang mendorong seseorang atau sekelompok orang untuk mencapai prestasi tertentu sesuai dengan apa yang dikehendakinya. Motivasi mempersoalkan bagaimana caranya mengarahkan daya dan potensi bawahan agar mau bekerja sama secara produktif berhasil mencapai dan mewujudkan tujuan yang telah ditentukan.

\section{Lingkungan Kerja}

Menurut Siagian (2015) mengemukakan bahwa lingkungan kerja adalah lingkungan dimana pegawai melakukan pekerjaannya sehari-hari. Lain halnya menurut Sedarmayanti (2013) mengemukakan bahwa suatu tempat yang terdapat sebuah kelompok dimana di dalamnya terdapatbeberapa fasilitas pendukung untuk mencapai tujuan perusahaan sesuai dengan visi dan misi perusahaan. 


\section{Kepuasan Kerja}

Kepuasan kerja karyawan harus diciptakan sebaik-baiknya supaya moral kerja, dedikasi, kecintaan dan kedisiplinan karyawan meningkat. Saat orang-orang berbicara mengenai sikap bekerja, mereka biasanya merujuk pada kepuasan kerja, yang menjelaskan suatu perasaan positif tentang pekerjaan yang dihasilkan dari suatu evaluasi pada karakteristik-karakteristiknya. Menurut Sutrisno (2014), kepuasan kerja adalah suatu sikap sikap karyawan terhadap pekerjaan yang berhubungan dengan situasi kerja, kerjasama antar karyawan, imbalan yang diterima dalam kerja, dan hal-hal yang menyangkut faktor fisik dan psikologis.

\section{Budaya Kerja}

Menurut Schein (2014) definisi budaya kerja adalah suatu pola asumsi dasar yang diciptakan, ditemukan, atau dikembangkan oleh kelompok tertentu sebagai pembelajaran untuk mengatasi masalah adaptasi eksternal dan integrasi internal yang terjadi dalam perusahaan dan oleh karena itu diajarkan kepada anggota-anggota baru sebagai cara yang tepat untuk memahami, memikirkan dan merasakan terkait dengan masalah-masalah tersebut.

\section{Alur Penelitian}

\section{Kurang oprimalnya disiplin kerja}

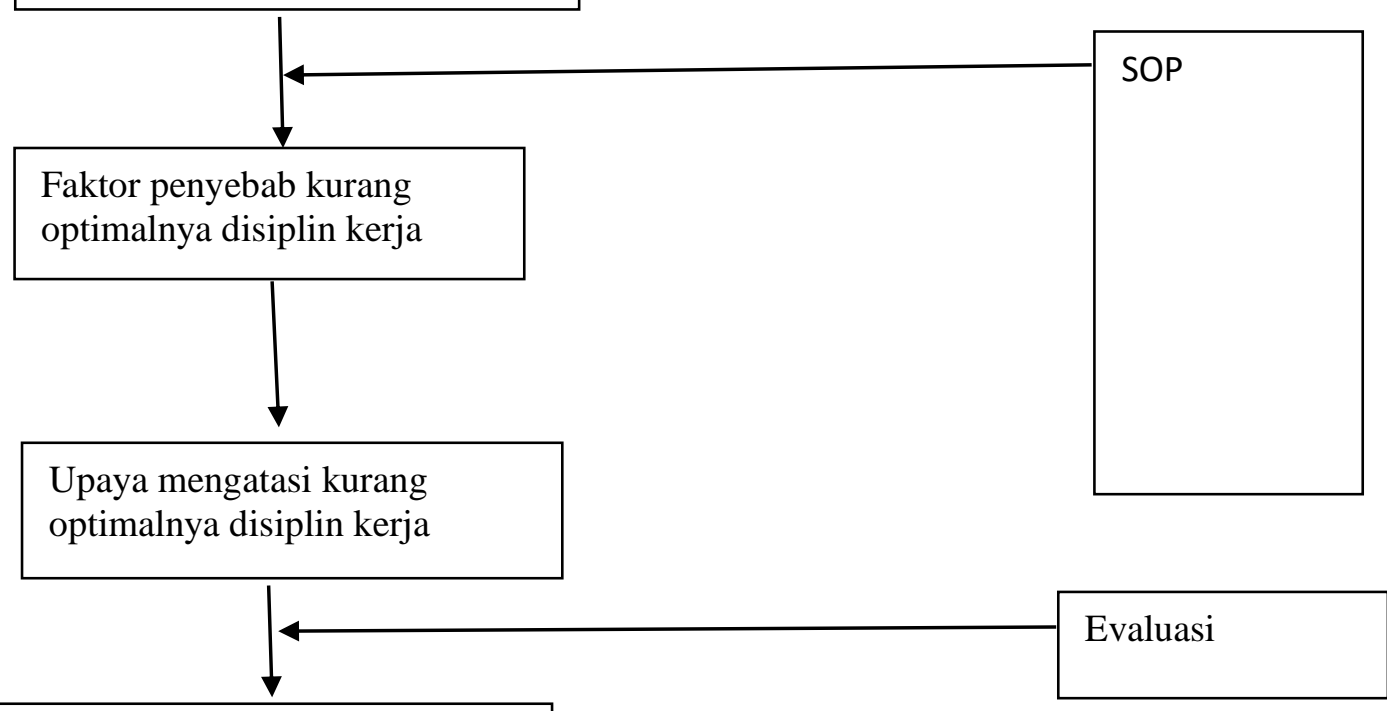

Solusi mengatasi kurang optimalnya disiplin kerja 


\section{Jenis Penelitian}

Untuk menjelaskan tentang upaya - upaya yang dilakukan MDS Paragon Semarang agar disiplin kerja karyawan di MDS Paragon Semarang menjadi lebih baik dan optimal, dengan unsur - unsur pokok yang harus ditemukan sesuai dengan rumusan masalah, tujuan dan manfaat penelitian, maka digunakan metode penelitian jenis Case Study ( Studi Kasus ). Case Study merupakan penelitian yang menggunakan bukti empiris dari satu atau lebih organisasi, dan peneliti berusaha mempelajari permasalahan dalam konteksnya. Definisi Case Study ini merupakan dalam konteks penelitian di bidang bisnis dan telematika.

Salah satu jenis penelitian kualitatif deskriptif adalah berupa penelitian dengan metode atau pendekatan studi kasus (Case Study). Penelitian ini memusatkan diri secara intensif pada satu obyek tertentu yang mempelajarinya sebagai suatu kasus. Data deskriptif diperoleh dalam sebuah penelitian kualitatif yang hasilnya dideskripsikan berdasarkan pada tujuan penelitian.

\section{Jenis Data Penelitian}

Data penelitian ini, data yang akan diperoleh berdasarkan sumbernya dan dapat diklasifiksikan dari dua sember yaitu:

1. Dalam penelitian ini peneliti melakukan observasi, wawancara mendalam, dokumentasi guna memperoleh data yang dibutuhkan.

2. Untuk penelitian ini data sekunder yang digunakan oleh peneliti berasal dari buku-buku literatur, buku data SOP Matahari Department Paragon Semarang, studi pustaka dan sebagainya

\section{Lokasi Penelitian}

Suatu penelitian memerlukan tempat penelitian yang dijadikan objek untuk memperoleh data, informasi dan keterangan yang diperlukan sehubungan dengan kepentingan penelitian. Penelitian ini dilakukan di MDS Paragon Semarang Jl. Pemuda No.118, Kota Semarang, Jawa Tengah 50138. 


\section{Subyek Dan Obyek Penelitian}

Dalam penelitian ini peneliti memiliki kriteria penetapan informan kunci yang dipilih adalah orang yang menguasai tentang materi yang akan diteliti, karyawan yang telah bekerja dari grand opening MDS Paragon Semarang sampai sekarang, serta dapat memberikan informasi yang akurat dan dapat dipercaya.

Dengan demikian informan kunci adalah orang yang dianggap penulis mampu menjelaskan dan memiliki pengetahuan - pengetahuan tentang keadaan keadaan yang terjadi pada suatu tempat atau kondisi karena keberadaannya yang sudah cukup lama di tempat tersebut.

\section{Metode Pengumpulan Data}

Menurut Sugiyono (2017) Teknik pengumpulan data merupakan langkah yang paling strategis dalam penelitian, karena tujuan utama dari penelitian adalah mendapatkan data. Teknik pengumpuan data di bagi menjadi 3 yaitu Observasi, Wawancara, Dokumentasi (Triangulasi).

\section{Teknik Analisis Data}

\section{Triangulasi Sumber}

Triangulangi sumber adalah untuk menguji krediabilitas data dilakukan dengan cara mengecek data yang telah diperoleh melalui beberapa sumber. Data yang telah di analisis oleh peneliti sehingga menghasilkan suatu kesimpulan selanjutnya memberikan kesepakatan (member check) dengan ketiga sumber data tersebut. Triangulasi sumber berarti, untuk mendapatkan data dari sumber yang berbeda-beda dengan teknik yang sama.

\section{Triangulasi Metode}

Triangulasi metode, yaitu dengan melakukan pengecekan data penelitian dengan teknik pengumpulan data yang berbeda yakni wawancara, observasi, dan dokumentasi sehingga data bersifat kredibel. 


\section{Narasi Data}

Dalam menarasikan data kualitatif ada beberapa hal yang perlu diperhatikan yaitu;

1. Tentukan bentuk (form) yang akan digunakan dalam menarasikan data.

2. Hubungkan bagiamana hasil yang berbentuk narasi itu menunjukan tipe/bentuk keluaran yang sudah di desain sebelumnya.

3. Jelaskan bagimana keluaran yang berupa narasi itu mengkoperasikan antara teori dan literasi-literasi lainnya yang mendukung topik.

\section{Hasil Dan Pembahasan}

\section{Analisis Data}

Tujuan dari analisis data adalah menyederhanakan data ke dalam bentuk lebih mudah dibaca dan diinterprestasi untuk menjawab pertanyaan penelitian. Dalam tahap ini hasil uji kredibilitas data ditampilkan dalam bentuk tabel triangulasi yang dilengkapi dengan uraian penjelasan isi tabel tersebut. Untuk mengetahui faktor - faktor yang terkait dengan kurang optimalnya disiplin kerja karyawan MDS yang terkait dengan kurang optimalnya disiplin kerja karyawan MDS Paragon Semarang, maka informan akan diberikan pertanyaan mengenai faktor - faktor yang berkaitan dengan kurang optimalnya disiplin kerja karyawan MDS Paragon Semarang.

\section{Ringkasan Temuan Deskripsi Hasil Temuan}

\begin{tabular}{|l|c|l|l|}
\hline Pertanyaan & Asisten Manajer & SPG 1 & SPG 2 \\
\hline Bagaimana & 1. Bekerja & 1. Bekerja & 1. Bekerja \\
SOP & sesuai SOP & & sesuai SOP \\
disiplin & & & \\
kerja di & & & \\
MDS & & & \\
Paragon & & & \\
Semarang? & & & \\
& & & \\
& & & \\
\hline
\end{tabular}




\begin{tabular}{|c|c|c|c|}
\hline $\begin{array}{l}\text { Apakah } \\
\text { penyebab } \\
\text { kurang } \\
\text { optimalnya } \\
\text { disiplin } \\
\text { kerja } \\
\text { karyawan } \\
\text { di MDS } \\
\text { Paragon } \\
\text { Semarang? }\end{array}$ & $\begin{array}{ll}\text { 1. } & \text { Kurang } \\
\text { mematuhi } \\
\text { peraturan }\end{array}$ & $\begin{array}{l}\text { 1. Kebiasaan } \\
\text { yang } \\
\text { menyebabka } \\
\mathrm{n} \\
\text { Tanggungja } \\
\text { wab rendah }\end{array}$ & $\begin{array}{l}\text { 1. Lingkungan } \\
\text { kerja }\end{array}$ \\
\hline $\begin{array}{l}\text { Apakah } \\
\text { MDS } \\
\text { Paragon } \\
\text { Semarang } \\
\text { mencari } \\
\text { solusi } \\
\text { dalam } \\
\text { mengatasi } \\
\text { kurang } \\
\text { optimalnya } \\
\text { disiplin } \\
\text { kinerja } \\
\text { karyawan? }\end{array}$ & $\begin{array}{l}\text { 1. Mengutamak } \\
\text { an } \\
\text { kesejahteraan } \\
\text { karyawan } \\
\text { 2. Motivasi }\end{array}$ & 1. Pengawasan & 1. Pengawasan \\
\hline
\end{tabular}

Dari tabel yang diperoleh dari hasil wawancara mendalam tersebut, dapat menjawab pertanyaan penelitian meliputi :

1. Bagaimana SOP disiplin kerja di MDS Pragon Semarang?

a. SOP dijalankan sesuai peraturannya

2. Apakah penyebab kurang optimalnya disiplin kerja karyawan di MDS Paragon Semarang?

a. Lingkungan kerja

Lingkungan kerja menjadi faktor penentu untuk karyawan yang kurang optimal dalam disiplin kerja.

b. Tanggung jawab rendah 
Tanggung jawab yang rendah menjadi faktor penentu utama untuk karyawan yang kurang optimal dalam disiplin kerja.

c. Inisiatif rendah

Insiatif ini juga menjadi faktor dari rendahnya disiplin kerja karyawan. Karena jika karyawan yang inisiatif menunjukkan adanya tingkat motivasi untuk diri sendiri yang tinggi, sehingga karyawan tersebut akan menunjukkan tingkat disiplin yang tinggi pula.

d. Kebiasaan

Alasan kebiasaan menjadikan karyawan juga melakukan tindakan kurang optimalnya disiplin dalam kerjanya, kebiasaan - kebiasaan yang sudah dibiasakan dan tidak dirubah akan menjadikan karyawan tidak akan bisa meningkatkan disiplin kerjanya.

3. Apakah MDS Paragon Semarang mencari solusi dalam mengatasi kurang optimalnya disiplin kinerja karyawan?

\section{a. Memotivasi}

MDS Paragon Semarang terutama karyawannya mengharapkan agar pimpinan lebih memberikan dorongan semangat dan perhatian seperti dengan memberikan motivasi-motivasi.

b. Pengawasan

Pihak karyawan berharap bisa lebih ketat daam pengawasan agar bisa menghimbau secara langsung bagaimana kinerja dari karyawan, guna untuk meningkatkan disiplin kerja karyawan.

\section{Kesimpulan}

Dari hasil penelitian ditemukan bahwa faktor terkait yang menyebabkan kurang optimalnya disiplin dalam kerja di MDS Paragon Semarang adalah kurang mematuhi peraturan SOP di perusahaan, kebiasaan yang menyebabkan 
tanggungjawab terhadap pekerjaan menjadi rendah dan lingkungan kerja itu sendiri.

\section{Saran}

Berdasarkan hasil penelitian yang telah dilakukan maka saran yang dapat diberikan dalam penelitian ini yaitu pihak pimpinan atau manajemen di MDS Paragon Semarang lebih sering mengawasi di lapangan dan harus tegas dalam memimpin agar karyawan tidak dengan mudah menyepelekan atau tidak meningkatkan disiplin kerja mereka. Serta tidak lupa pihak pimpinan memberikan dorongan motivasi, perhatian yang lebih agar karyawan juga ada keasadaran diri untuk mau meningkatkan disiplin kerjanya.

\section{Keterbatasan Penelitian}

Dalam penelitian ini, peneliti melakukan pendekatan secara terbuka dan melakukan komunikasi dengan baik. Namun terdapat beberapa hal yang membatasi penelitian ini di antaranya :

1. Penelitian dilakukan di Perusahaan jadi kemungkinan hasilnya tidak sama dengan penelitian yang dilakukan di Restoran. Peneliti selanjutnya kemungkinan dapat memanfaatkan instrumen ini untuk melakukan penelitian yang terkait dengan cara memperbaiki atau menyesuaikan dengan tujuan dari penelitian yang dikehendaki.

2. Penelitian ini tergantung kepada interpretasi peneliti tentang makna yang tersirat dalam wawancara sehingga kecenderungan untuk bias masih tetap ada. Untuk mengurangi bias maka dilakukan proses triangulasi, yaitu triangulasi sumber dan metode. Triangulasi sumber dilakukan dengan caracross check dengan fakta dari informan yang berbeda dan dari hasil penelitian lainnya. Sedangkan triangulasi metode dilakukan dengan cara menggunakan beberapa metode dalam pengumpulan data, yaitu observasi dan wawancara mendalam. 


\section{Agenda Penelitian Selanjutnya}

Karena masih adanya keterbatasan dalam penelitian ini maka untuk mengatasinya agenda penelitian mendatang (future research) diperlukan perbaikan, yaitu penelitian mendatang hendaknya mengarahkan penelitian pada obyek penelitian yang lebih luas, untuk mendapatkan hasil yang lebih umum terhadap faktor - faktor yang berpengaruh terhadap kurang optimalnya disiplin kerja.

\section{Daftar Pustaka}

A, A, Anwar Prabu Mangkunegara. 2009. Manajemen Sumber Daya Manusia. Bandung: PT. Remaja Rosdakarya.

A, F Stoner, James dan Edward Freeman, 2010. Manajemen Jilid I, terj. Alexander Sindoro, Jakarta: PT Prahallindo,

A, Pribadi, Benny. 2013. Model Desain Sistem Pembelajaran. Jakarta: PT Dian Rakyat.

Arikunto, S. 2013. Prosedur Penelitian: Suatu Pendekatan Praktik. Jakarta: Rineka Cipta.

Antonius, Bugaran Simanjuntak. 2009, Konflik Status Dan Kekuasaan Orang Batak Toba, Yayasan Obor Indonesia: Jakarta

Bass, B. \& Avolio, B., 2011, Full range leadership development: Manual for multifactor leadership questonaire, Redwood City, California: Mind Garden.

Basrowi Sukidin, Basrowi, Suranto.2012. Manajemen Pendidikan Penelitian . Penerbit Insan cendekia.

Danim, Sudarwan. 2012. Motivasi Kepemimpinan dan Efektivitas Kelompok. Jakarta : Rineka Cipta.

Dessler, Gary, 2011.Manajemen sumber daya manusia. Penerbit Indeks, Jakarta.

Flippo, Edwin B. 2011, Manajemen Personalia. PT. Gelora Askara Pratma, Jakarta.

Gibson, et al. 2009. Organisasi. Edisi ke lima. Jakarta : Erlangga.

Gunawan, Imam. 2013. METODE PENELITIAN KUALITATIF.: Teori dan Praktik Jakarta: PT Bumi Aksara.

Hasibuan, Malayu S.P. 2016.Manajemen Sumber Daya Manusia. Edisi Revisi. Jakarta: Penerbit PT Bumi Aksara. 
Indriantoro, Nur and Bambang Supomo. 2014. Metodologi Penelitian Bisnis Untuk Akuntansi \& Manajemen. Edisi 1. Cetakan ke-12. Yogyakarta: BPFE.

Lestari, Puji. 2009. Analisis Interaksi Motivasi Kerja Karyawan dan Kepemimpinan Atasan yang di Persepsikan Karyawan di PT. Pertamina (Persero) (Melalui Pendekatan Model Herzberg dan Bass). Jakarta: Universitas Indonesia.

Luthans, Fred. 2009. Perilaku Organisasi. Edisi Sepuluh. Yogyakarta: Andy Offset.

Mathis, Robert L. dan John H. Jackson. 2012. Manajemen Sumber Daya Manusia, Edisi Pertama. Salemba Empat, Jakarta

Miftah, Thoha. 2012. Prilaku Organisasi Konsep Dasar Dan Implikasinya. Jakarta: PT. Raja Grafindo Persada.

Moeheriono, 2014. Pengukuran Kinerja Berbasis Kompetensi, Edisi Revisi. Jakarta: Rajawali Pers.

Moleong, L. J. 2010. Metodologi Penelitian Kualitatif, Bandung: Remaja Rosdakarya.

Nawawi, Hadari, 2011, Manajemen Sumber Daya manusia, Yogyakarta: Gadjah Mada University Press.

Ndraha, Taliziduhu, 2012, Pengantar teori Pengembangan Sumber Daya Manusia, Rineka Cipta, Jakarta.

Poerwandari, E, Kristi. 2009. Pendekatan Kualitatif.Cetakan ketiga. Depok: Lembaga Pengembangan Sarana Pengukuran dan Pendidikan Psikologi Fakultas Psikologi UI.

Reitz H Joseph, and Jewell Linda N. 1981. Group Effectiveness in Organizations. Universitas Michigan: Scott Foresman.dalam Indah Dwi Rahayu 2017, dalam melaksanakan aktivitas pemimpin ada beberapa faktor-faktor yang mempengaruhi gaya kepemimpinan. Jakarta.

Rivai, Veithzal dan Ella Sagala, 2013. Manajemen Sumber Daya Manusia untuk Perusahaan, Rajawali Pers, Jakarta.

Robbins, P. Stephen \& Coutler, Mary.2016, Human Resources Management, Edisi 16, Jilid 1, Salemba Empat, Jakarta.

Schein, Edgar, H 2014. OrganizationalCultureandLeadership. SanFrancisco :Josey-Bass Publishers

Sedarmayanti, 2013, Manajemen Sumber Daya Manusia, Bandung: Refika Aditama. 
Sembiring, Robert K. 2010. Pendidikan Matematika Realistik Indonesia (PMRI) : Perkembangan dan Tantangannya.Vol.1 No. 1 Juli 2010, pp. 11-16.

Simamora, Henry. 1997. Manajemen Sumber Daya Manusia. Yogyakarta: BPFE UGM dalam Sari Yessy Anita. 2014. Pengaruh Gaya Kepemimpinan, Motivasi dan Komunikasi Terhadap Kinerja Karyawan PT Masaji Tatana Container Kota Semarang. Skripsi S1. Surakarta: Universitas Muhammadiyah Surakarta

Sinambela, Lijan. 2012. Kinerja Pegawai: Teori, Pengukuran dan Implikasi. Yogyakarta : Graha Ilmu.

Sondang P Siagian, 2015, Manajemen Sumber Daya Manusia, Bumi Aksara,Jakarta.

Stephen, Robbins , 2015, Perilaku Organisasi, Penerbit Salemba Empat, Jakarta.

Sugiyono, 2017. Metode Penelitian Kuantitatif, Kualitatif, dan R\&D. Bandung : Alfabeta, CV

Supriyadi, Gering, dan Triguno, 2011 .Budaya Kerja Organisasi Pemerintah. Salemba, Jakarta.

Supriyati. 2011. Metodologi Penelitian. Bandung: Labkat press.

Sutikno, sobry M. 2014 .Pemimpin Dan Gaya Kepemimpinan, Edisi Pertama Lombok: Holistica.

Sutrisno, Edy. 2014. Manajemen Sumber Daya Manusia Edisi pertama. Jakarta: Kencana Prenada Media Group.

Suwatno, dan Donni Juni Priansa. 2016. Manajemen SDM dalam Organisasi Publik dan Bisnis. Bandung: Alfabeta.

Tampi, Bryan Johannes. 2012. Pengaruh Gaya Kepemimpinan dan Motivasi Terhadap Kinerja Karyawan Pada PT. Bank Negara Indonesia Tbk (regional Sales Manado. Journal "Acta Diurna'Volume III. No.4. Tahun 2014. Manado: Universitas Sam Ratulangi.

Terry, George R. dalam Malayu Hasibuan. 2014. Dasar-dasar Manajemen, Jakarta : Bumi Aksara

Veithzal Rivai, 2014. Manajemen Sumber Daya Manusia untuk Perusahaan, Edisi ke 6, PT. Raja Grafindo Persada, Depok.

Wiratama, Nyoman J.A. dan Sintaasih, D.K. 2013. "Pengaruh Kepemimpinan, DIKLAT, dan Dipsiplin Kerja Terhadap Kinerja Karyawan PDAM Tirta Mangutama Kabupaten Bandung”. Jurnal Manajemen, Strategi Bisnis, dan Kewirausahaan. Vol. 7, No.2. 